\title{
MP29-02*'s advanced delivery system contributes to its efficacy in patients with moderate/severe seasonal allergic rhinitis
}

\author{
Glenis Scadding ${ }^{1}$, Claus Bachert ${ }^{2}$, Peter Hellings ${ }^{3^{*}}$, Wytske Fokkens ${ }^{4}$, Ullrich Munzel ${ }^{5}$, Ralph Mösges ${ }^{6}$ \\ From The 10th Symposium of Experimental Rhinology and Immunology of the Nose (SERIN 2015) \\ Stockholm, Sweden. 19-21 February 2015
}

\section{Background}

Four previously published trials assessed the efficacy of MP29-02* (a novel intranasal formulation of azelastine hydrochloride (AZE) and fluticasone propionate (FP) in an advanced delivery system) in seasonal allergic rhinitis (SAR) [1,2]. The first study compared MP29-02* to marketed AZE and FP [2]. The others compared MP29-02* to AZE and FP in the MP29-02* vehicle and delivery device (i.e. re-formulated comparators) [1]. FP contained within MP29-02* has a unique PK fingerprint [3]. The aim of this analysis was to demonstrate that formulation/device contribute to MP29-02*'s clinical efficacy.

\section{Methods}

Four thousand and five moderate/severe SAR patients ( $\geq 12$ yrs old) were randomized into 4 double-blind, placebo (PLA)-controlled trials. Each trial comprised 4 groups: MP29-02*, AZE, FP and PLA nasal sprays, and was conducted for 14 days. Total daily dose of AZE and FP were $548 \mu \mathrm{g}$ and $200 \mu \mathrm{g}$, respectively. Change from baseline (CFB) in reflective total nasal symptom score (rTNSS) over 14-days was the primary outcome. CFB in reflective total ocular symptom score (rTOSS) and individual nasal and ocular symptoms was assessed secondarily. Time to achieve at least a 50\% rTNSS reduction from baseline was assessed post-hoc by Kaplan Meier estimates and log rank tests. The formulation/device effect of MP29-02* was quantified by comparing treatment differences obtained with MP29-02* vs marketed FP and MP29-02* vs reformulated FP for these endpoints.

${ }^{3}$ University Hospitals Leuven, Dept of Otorhinolaryngology, Head \& Neck Surgery, Leuven, Belgium

Full list of author information is available at the end of the article

\section{Results}

For all efficacy variables assessed, the treatment difference was greater for MP29-02* vs marketed-FP than for MP29$02 *$ vs re-formulated-FP. For rTNSS, the difference between MP29-02* and marketed-FP was -1.47 , compared to -0.76 vs reformulated-FP; a formulation/device effect of 0.71 . Similarly for rTOSS a formulation/device effect of 0.70 was observed. A formulation/device effect was observed for relief of all individual nasal and ocular symptoms (e.g. 0.23 effect for congestion; 0.34 effect for ocular itching). Finally, MP29-02*-patients achieved a $\geq 50 \%$ rTNSS reduction $\leq 6$ days faster than marketed-FP and $\leq 3$ days faster than reformulated-FP, a formulation/device effect of $\leq 3$ days.

\section{Conclusion}

Formulation and device contribute to MP29-02"'s superior efficacy over currently considered firstline therapy, making MP29-02* a new class of treatment for AR.

"Dymista

\begin{abstract}
Authors' details
${ }^{1}$ The Royal National Throat Nose and Ear Hospital, London, UK. ${ }^{2}$ Ghent University Hospital, Department of Oto-Rhinolaryngology, Ghent, Belgium. ${ }^{3}$ University Hospitals Leuven, Dept of Otorhinolaryngology, Head \& Neck Surgery, Leuven, Belgium. ${ }^{4}$ Academic Medical Center, Department of Otorhinolaryngology, Amsterdam, Netherlands. ${ }^{5}$ Meda, Corporate Clinical Affairs, Bad Homburg, Germany. 'University of Cologne, IMSIE, Cologne, Germany.
\end{abstract}

Published: 26 June 2015

\section{References}

1. Carr W, Bernstein P, Lieberman, Meltzer E, Bachert C, Price D, et al: A novel intranasal therapy of azelastine with fluticasone for the treatment of allergic rhinitis.. JACl 2012, 129(5):1282-1289.

2. Meltzer E, Ratner P, Bachert C, Carr W, Berger W, Canonica GW, et al: Clinically relevant effect of a new intranasal therapy (MP29-02) in 
allergic rhinitis assessed by responder analysis.. Int Arch Allergy Immunol 2013, 161(4):369-377.

3. Derendorf $\mathrm{H}$, Munzel U, Petzold U, Maus J, Mascher $\mathrm{H}$, Hermann R, et al: Bioavailability and disposition of azelastine and fluticasone propionate when delivered by MP29-02, a novel aqueous nasal spray. Int Arch Allergy Immunol 2013, 74(1):125-133.

\section{doi:10.1186/2045-7022-5-S4-P36}

Cite this article as: Scadding et al: MP29-02*'s advanced delivery system contributes to its efficacy in patients with moderate/severe seasonal allergic rhinitis. Clinical and Translational Allergy 2015 5(Suppl 4):P36.

Submit your next manuscript to BioMed Central and take full advantage of:

- Convenient online submission

- Thorough peer review

- No space constraints or color figure charges

- Immediate publication on acceptance

- Inclusion in PubMed, CAS, Scopus and Google Scholar

- Research which is freely available for redistribution

Submit your manuscript at www.biomedcentral.com/submit
C Biomed Central 